\title{
FIRST SUPPLEMENT TO THE INDEX OF VECTORS OF VIRUS DISEASES OF PLANTS *
}

\author{
Mestrite T. Cook, Plant Pathologist, \\ Agricultural Experiment Station, Río Piedras, Puerto Rico.
}

This supplement is submitted to the workers on virus diseases of plants hoping that it may be useful in the advancement of this branch of science which is a combination of plant pathology and entomology. It makes the original index fairly complete. About twenty five genera and more than sixty five species of insects are added to the original list. Many new records of transmission are also added to the list.

AMPHOROPHORA ROSSI

1933. Yellow dwarf of onion. Onion to onion. Drake, Tate \& Harris. Iowa.

AMPHOROPHORA RUBI

1933. Yellow dwarf of onion. Onion to onion. Drake, Tate \& Harris. Iowa.

AMPHOROPHORA RUBICOLA

1932. Bennett says this species is less important than A. rubi. ANOECIA sp.

1933. Yellow dwarf of onion. Onion to onion. Drake, Tate \& Harris. Iowa.

ApHIS sp.

NoTE: A letter from Dr. Schultz states that he and Dr. Folsom obtained transmission of mild mosaic (1918), leaf roll (1919), spindle tuber (1922), rugose mosaic (1922), leaf rolling mosaic (1922), unmottled curly dwarf (1922) and streak (acropetal necrosis) (1924).

1925. Mosaic. Physalis pubescens to Cucumis sativus, Walker. U. S.

1925. Mosaic. Physalis sativus, Lathyrus odoratus and Trifolium pratenese to $C$. sativus and $L$. odoratus. Doolittle \& Jones. U. S.

1925. Mosaic. Physalis pubescens to P. pubescens. Walker. APHIS AGERATOIDIS

1933. Yellow dwarf of onion. Onion to Onion. Drake, Tate \& Harris. Iowa.

APHIS CARDUI

1933. Yellow dwarf of onion. Onion to Onion. Drake, Tate \& Harris. Iowa.

* Journal of the Department of Agriculture of the University of Puerto Rico. 19(3): 407-420. July, 1935 . 
APHIS DECEPTA

1933. Yellow dwarf of onion. Onion to Onion. Drake, Tate \& Harris. Iowa.

\section{APHIS FABAE}

1927. Mosaic. Vicia faba to V. faba. Böning, Germany.

1929. Mosaic. Phaseolus vulgaris to Vicia faba. Elze. Holland. A record for 1927 was not positive.

1930. Mosaic. Sugar beet to Chenopodium album, Amaranthus and S. arvensis. Novinenko. Ukarane.

\section{APHIS FORBESI}

1933. Yellow dwarf of onion. Onion to Onion. Drake, Tate \& Harris. Iowa.

1934. Mosaic of sugar beet to several plants. Verplancke. Belgium.

\section{APHIS GOSSYPII}

1914. Mosaic, Lathyrus odoratus to L. odoratus. Taubenhaus. Delaware.

1925. Yellow fiat mosaic. Easter lily to Eastern lily. Ogilvie. Bermuda.

1925. Garden pea \& sweet pea to garden pea \& sweet pea.

Doolittle \& Jones. U. S. Note. Hoggan says that this is Illinoia sp.

1925. Mosaic. Red clover to garden pea. Doolittle \& Jones. U. S.

1925. Mosaic. Cucurbits to cucurbits. Doolittle \& Jones. U. S.

1925. Mosaic. Easter lily to Easter lily. Gutermann. New York.

1925. Mosaic. Cucumber to Physalis pubescens. Walker. U. S, 1925. Mosaic. Celery to celery and cucumber. Elmer. Iowa. 1933. Mosaic. Bean to bean. Zaumeyer. U.S.

1933. A virus disease of Lilium longiflorum var. formosum and var.. erabu. Also L. auratum. Pape. Germany,

1935. Fern leaf of tomato. Jones \& Burnett. Washington. Note. Same as cucumber mosaic.

1934. Mosaic. Vegetable marrow (Cucurbita?) to Vegetable marrow. Gigante. Italy.

ApHis MAIDIS (A. ADUSTA)

1929. Storey, reported a strain of mosaic transmitted to maize and Sorghum but not to sugar cane.

1923. Sugar cane mosaic. Saccharum officinarum to Miscanthus sinensis, Syntherisma anguinalis, Paspalum boscianum, Holcus sorghum, Brachiaria platyphylla, Chaetochloa lutescens, C. magna and Panicum dichotomiflorum. Brandes \& Klaphaak. U. S.

1933. Yellow dwarf of onion. Onion to onion. Drake, Tate \& Harris. Iowa. 
APHIS MEDICAGINIS

1936. Mosaic. Bean to bean. Zaumeyer \& Kearns. U. S.

APHIS OENOTHERAE

1933. Yellow dwarf of onion. Onion to onion. Drake, Tate \& Harris. Iowa.

APHIS POMI

1933. Yellow dwarf of onion. Onion to onion. Drake, Tate \& Harris. Iowa.

APHIS RHAMNI

Said to carry a virus of Cirsium sp. and S. tuberosum. No data. APHIS RUBIPHILA

1927. Curl. Raspberry to raspberry. Bennett, Michigan. May rarely carry mosaic.

APHIS RUMICIS

1931. Yellows. Spinach to spinach. Blattny. Czechoslovakia.

1934. Mosaic. Vicia faba to $V$. faba. Imai. Japan.

1935. Sore shin of Lupinus angustifolius. Broad bean to broad bean. Chamberlain. Australia.

APHIS SPIRAECOLA

1936. Mosaic. Bean to bean. Zaumeyer \& Kearns. U. S.

APHIS VIBURNICOLA

1933. Yellow dwarf. Onion to onion. Drake, Tate \& Harris. Iowa.

AULACORTHUM PELARGONII

1934. Mosaic of beet to several hosts. Verplancke. Belgium.

Bemisia sp.

1932. Kroepoek of tobacco \& Zinnia elegans. Kerling. Java.

BEMISIA FASCIALIS

1931. Leaf curl. Cotton to cotton. Kirkpatrick. Sudan.

Bemista GOSSYPIPERDA

1935. Azerbaijan. Cotton to cotton. Verderevsky. Russia.

BEMisia NIGERNIENSIS

1934. Probably carries krul (curl) and kroepoek (crinkle) of tobacco. Thung. Java.

1935. Mosaic. Cassava to cassava. Golden. Southern Nigeria. Record not positive.

BREVICORYNE BRASSICAE

1933. Mosaic. Bean to bean. Zaumeyer.

1933. Yellow dwarf of onion. Onion to onion. Drake, Tate \& Harris. Iowa.

Calocoris bipunctatus

1933. Virus A. Potato to potato. Loughnane. Ireland. 
Calaphis betulella

1933. Yellow dwarf of onion. Onion to onion. Drake, Tate \& Harris. Iowa.

Capitophorus fluveolus

1933. Yellow dwarf of onion. Onion to onion. Drake, Tate \& Harris. Iowa.

CAPITOPHORUS RIBIS

1933. Yellow dwarf of onion. Onion to onion. Drake, Tate \& Harris. Iowa.

Chaitophorus Quercicola

1933. Yellow dwarf of onion. Onion to onion. Drake, Tate \& Harris. Iowa.

Capitophorus viminalis

1933. Yellow dwarf of onion. Onion to onion. Drake, Tate \& Harris. Iowa.

Chlorita flavecens (Empoasca)

1928. Mosaic. Celery to celery Blattny. Czechoslovakia.

Chlorita solani

Mosaic. Beans to beans. No data.

Cicadula divisa

1934. California aster yellows. Aster to potato. Severin \& Haasis. California.

Cicadula sexnotata ( $C$. divisa)

1924. Yellows. Aster to aster. Kunkle. New York.

1929. Celery yellows. Celery to celery. Severin. Calif. Same as aster yellows.

1930. Yellows. Carrot, parsley \& parsnip to aster \& celery. Severin. California. This virus is identical with California aster \& celery yellows.

1930. Yellows. Aster \& celery to parsley. Severin. California.

1932. California yellows. Aster to aster. Kunkel. New York. 1932. California yellows. Celery to aster. Kunkel. New York. 1932. California yellows. Carrot to aster. Kunkel. New York. 1932. Yellows. Carrot to aster \& celery and back. Severin, California.

1932. Yellows. Celery to aster \& celery and back. Severin. California.

Note: The last three are same as California aster yellows.

1932. Yellow dwarf of onion. Onion to onion. Drake, Tate \& Harris. Iowa.

\section{Cicadulina zeaE}

1931. Streak. Corn to corn. Tanganyika. Storey.

Clavigerus salicis

1933. Yellow dwarf of onion. Onion to onion. Drake, Tate \& Harris. Iowa. 
Diabrotica DUODECIMPUNCTATA

1935. Fern leaf of tomato. Jones \& Burnett. Washington.

Diabrotica vittata

1935. Fern leaf of tomato. Jones \& Burnett. Washington.

Same as cucumber virus.

DREPANAPHIS ACERIFOLIAE

1933. Yellow dwarf of onion. Onion to onion. Drake, Tate \& Harris. Iowa.

\section{DORALyS FABAe}

1934. Mosaic. Beet to other hosts. Verplancke. Belgium.

Empoasca fabae

1928. Yellow top of alfalfa. Appears to be associated with this insect. Granovsky. Wisconsin. There may be an earlier record.

EMPOASCA MALI

Yellows. Bean to bean. R. C. Smith \& Barker. Haiti. It has not been proven definitely that this disease is due to a virus.

Epitetranychus althaeae

1935. Virus disease. Legume to legume. Dounine, Russia. No definite data.

EPITRIX CUCUMERIS

1924. Mosaic. Tomato to tomato. Dickson. Canada.

Eutettix tenellus

1927. Curly top of sugar beet. Sugar beet to tomato. McKay \& Dykstra. Pacific Coast.

Tomato yellows (curly top of sugar beet). Tomato to tomato. McKay \& Dykstra. Oregon.

HYALOPTERIS ATRIPLICIS

1933. Mosaic. Bean to bean. Zaumeyer. U.S.

1933. Yellow dwarf of onion. Onion to onion. Drake, Tate \& Harris. Iowa.

1933. Mosaic. Pisum sativum to P. sativum. Doolittle \& Jones. U. S.

HYLAOPTERIS PRUNI

1933. Yellow dwarf of onion. Onion to onion. Drake, Tate \& Harris. Iowa.

Hysteroneura SETARIAE

1936. Mosaic. Sugar cane to Sugar cane. Ingram \& Summers. Louisiana. 
ILLINOIA PISI

1934. Common bean mosaic. Bean to bean. Price. New Jersey.

1934. Yellow bean mosaic. Bean to bean. Price. New Jersey.

1934. Mosaic. Alfalfa to alfalfa. Price. New Jersey.

ILIINOIA SOLANIFOLII

1933. Mosaic. Bean to bean. Zaumeyer. U.S.

LYGUS PRATENSIS

1935. Mosaic. Swede to swede. Pape, Germany.

Macrosiphum sp.

1918. Spinach blight. Spinach to spinach. McClintock \& Smith. Virginia.

1933. Virus A. Potato to potato. Loughnane. Ireland. Mosaic of sugar beet. No data.

MACROSIPHUM AMBROSIAE

1933. Mosaic. Bean to bean. Zaumeyer. U.S.

1933. Yellow dwarf of onion. Onion to onion. Drake, Tate \& Harris. Iowa.

MACROSIPHUM ARTEMESIAE

1933. Yellow dwarf of onion. Onion to onion. Drake, Tate \& Harris. Iowa.

Macrosiphum Gei ( $M$. solanifolii)

1935. Fern leaf of tomato. Jones \& Burnett. Washington.

Same as cucumber mosaic.

1931. Mosaic. Pea to pea. Osborn. New Jersey.

Macrosiphum gravicorus

1933. Yellow dwarf of onion. Onion to onion. Drake, Tate \& Harris. Iowa.

Macrosiphum impatienticolens $S^{\circ}$

1933. Yellow dwarf of onion. Onion to onion. Drake, Tate \& Harris. Iowa.

Macrosiphum PELARgonium

1927. Mosaic. Vicia faba to V. faba. Böning. Germany.

1930. Leafroll of potato. Potato to potato. Oregon.

Macrosiphum pisi

1930 Leafroll of potato. Potato to potato. Oregon.

1932. Mosaic. Clover to elover. Dickson. Canada. He used

Trifolium pratense, T. hybridum, T. repens, T. incarnatum, M. lupina, \& $M$. officinalis.

1933. Yellow dwarf of onion. Onion to onion. Drake, Tate \& Harris. Iowa.

Macrosiphum purpurascens

1933. Yellow dwarf of onion. Onion to onion. Drake, Tate \& Harris. Iowa. 
Macrosiphum rosae

1933. Yellow dwarf of onion. Onion to onion. Drake, Tate \& Harris. Iowa.

Macrosiphum RUdBeCKIAE

1933. Yellow dwarf of onion. Onion to onion. Drake, Tate \& Harris. Iowa.

Macrosiphum SOLANIFOLII

1933. Yellow dwarf of onion. Onion to onion. Drake, Tate \& Harris. Iowa.

1933. Mosaic. Cucumber to spinach. Hoggan. Wisconsin.

1923. Leafroll. Potato to potato. Schultz \& Folsom. Maine.

1923. Spindling tuber. Potato to potato. Schultz \& Folsom. Maine.

1928. Mosaic. Sugar beet to sugar beet. van der Meulen. Holland.

1933. Veinbanding. Potato to potato, Koch. Wisconsin.

1935. Calico. Potato to potato. Porter California.

MACROSIPHUM SONCHI

1935. Mosaic. Lettuce to lettuce. Ogilvie. England. Suspected as result of preliminary experiments.

Macrosiphum tabaCI

1914. Mosaic. Tobaceo to tobaceo. Allard. Washington. Not proven by cage experiments.

Macrosiphum taraxaci

1933. Yellow dwarf of onion. Onion to onion. Drake, Tate \& Harris. Iowa.

Macrosiphum ulmartae

1928. Mosaic. Sugar beet to sugar beet \& potato. van der Meulen \& Quanjer. Holland.

Mamestra brassicae

1927. Mosaic. Potato to potato. Elze. Holland.

Monellia caryella

1933. Yellow dwarf of onion. Onion to onion. Drake, Tate \& Harris. Iowa.

MONELLIA CARYAE

1933. Yellow dwarf of onion. Onion to onion. Drake, Tate \& Harris. Iowa.

Myzocaldis aLHambra

1933. Yellow dwarf of onion. Onion to onion. Drake, Tate \& Harris. Iowa.

Myzoncallis asclepiadis

1933. Yellow dwarf of onion. Onion to onion. Drake, Tate \& Harris. Iowa. 
MYZoCALLIS ONONIDIS

1933. Yellow dwarf of onion. Onion to onion. Drake, Tate \& Harris. Iowa.

Myzus CERASI

1933. Yellow dwarf of onion. Onion to onion. Drake, Tate \& Harris. Iowa.

Myzus CiRcumflexus

1921. Mosaic. Chinese mustard. \& turnip. to some. Schultz. Maine.

1922. Mosaic. Beet to beet. Robbins. Clorado.

1922. Mosaic. Beet to beet. Robbins. Colorado.

1932. Mosaic. Potato to potato. McKay \& Dykstra. Oregon. 1932. Mild mosaic. Potato to potato. MeKay \& Dykstra. Oregon.

1932. Leaf rolling mosaic. Potato to potato. McKay \& Dykstra. Oregon.

1932. Crinkle. Potato to potato. McKay \& Dykstra. Oregon.

MYZUS FRAGIFOLII

1933. Crinkle. Strawberry to strawberry. Vaughan. Oregon.

Mrzus HIERACII

Mosaic. Lettuce to lettuce. Böning. Germany.

MYzus MONARDAE

1933. Yellow dwarf of onion. Onion to onion. Drake, Tate \& Harris. Iowa.

Myzus persicae

1919. Mild mosaic. Potato to potato. Schultz \& Folsom. Maine.

1928. Mosaic. Vicia faba. var. major, Sinapsis alba. Rumex domesticus, R. crispus, Tusilago farfara, Polygonum persicaria. van der Meulen. Holland.

1929. Veinbanding. Tobacco to tobacco. Valleau \& Johnson. Kentucky.

1930. Crinkle of potato. Potato to tobaceo. K. M. Smith. England. Note-Transmits virus $\mathrm{Y}$ only. Both $\mathrm{X}$ and $\mathrm{Y}$ are transmitted by needle.

1931. Cucumber mosaic. Tomato to tobacco.

1932. Spotted wilt of tomato. Datura stramonium \& Capsicum sp. to D. stramonium \& Capsicum sp. K. M. Smith. England. 1933. Crinkle of strawberry. Strawberry to strawberry.

1933. Crinkle of strawberry. Strawberry to strawberry. Vaughan. U. S.

1933. Leaf roll. Potato to S. dulcamara, S. villosum, and $D$. stramonium. Dykstra. U. S.

1933. Veinbanding. Potato to tomato, Dykstra reported that: this component only was transmitted from rugose mosaic.

1933. Virus A of potato. Potato to potato. Clinch. Ireland. 1933. Leaf roll of potato. Potato to tomato, pepper, D. stramonium, D. tatula, S. dulcamara and S. nigrum. 
1933. Mosaic. Bean to bean. Zaumeyer. U.S.

1933. Yellow dwarf of onion. Onion to onion. Drake, Tate \& Harris. Iowa.

1934. Bigarrure of potato. Verplancke, Belgium.

1935. Fern leaf of tomato. Tomato to tomato. Jones \& Burnett. Washington. They believe this is cucumber virus.

1935. Yellow mosaic. Cucumber to cucumber. Hoggan. Wisconsin.

1934. Virus $\mathrm{Y}$ of potato. Transmitted independently of the $\mathrm{X}$ virus when associated. K. M. Smith \& Dufrenoy. England. 1935. Sore shin of Lupinus angustifolia. Garden pea to garden pea. Chamberlain. Australia.

1935. Mild mosaic. Cucumber to cucumber. Hoggan. Wisconsin.

NoтE: Valleau \& Johnson. Kentucky say that "Myzus persicae", rarely if ever transmits the healthy potato virus, while it regularly transmits the vein. banding virus from virus mixtures.

NoTE: Mosaic of Cheiranthus cheiri appears transmitted among several hosts, especially Cruciferae.

1928. Mosaic. Sugar beet to sugar beet, potato \& spinach. van der Meulen \& Quanjer. Holland.

Mrzus porosus

1933. Yellow dwarf of onion. Onion to onion. Drake, Tate \& Harris. Iowa.

Myzus pseudosolani

1931. Leafroll. Potato to potato. Murphy \& McKay. Ireland.

1929. K. M. Smith. England. 1931.

1931. Tobaceo mosaic and yellow mosaic of tobacco from tomato but not from tobaceo. Hoggan. Wisconsin.

Mrzus solanifoliI (Macrosiphum gei)

1926. Mosaic. Potato. Murphy \& McKay. Ireland.

Nematus ventricosa.

1930. Mosaic. Convolvulus arvensis to C. arvensis. Blattny. Czechoslovakia.

NEOPHOTETTIX APICALIS var. CINCTICEPS

NoTE: The period of study of the dwarf of rice appears to have started about 1897.

\section{PeRIPHYLlus NeGUNDINIS}

1933. Yellow dwarf of onion. Onion to onion. Drake, Tate \& Harris. Iowa.

PERIPHYLlUS POPULICOLA

1933. Yellow dwarf of onion. Onion to onion. Drake, Tate \& Harris. Iowa.

Phillaenous spumarius

1923. Leaf roll. Potato to potato. Murphy. Ireland. 
Prociphilus CORRUGatans

1933. Yellow dwarf of onion. Onion to onion. Drake, Tate \& Harris. Iowa.

\section{PsYLLOIDES AFFINIS}

1923. Leaf roll of potato. Potato to potato. Murphy. Ireland. Rhopalosiphum (myzus) PERsicae

1928. Mosaic. Vicia faba var. major to $V$. faba var. major. van der Meulen. Holland.

RHOPALOSIPHUM PSEUdOBRASSICAE

1933. Yellow dwarf of onion. Onion to onion. Drake, Tate \& Harris. Iowa.

1936. Mosaic. Bean to bean. Zaumeyer \& Kearns. U. S.

RHOPALOSIPHUM RHOIS

1933. Yellow dwarf of onion. Onion to onion. Drake, Tate \& Harris. Iowa.

Thamnotettix geminatus

1934. California aster yellows and celery yellows. Severin. California.

Thamnotettix montanus

1934. California aster yellows \& celery yellows. Severin. California.

THRIPS sp.

1935. Stolbur. Appears to be vector of this disease which occurs on Lycopersicon esculentum, Atropo belladonna, Datura stramonium, Nicotiana tabacum and Convolvulus arvensis, Koratshevsky, Russia.

THRIPS TABACI

1927. Mosaic. Spinach \& beet to spinach \& beet. Proof not positive.

Potato leaf roll. K. M. Smith used many hosts.

1932. Virus disease of tobacco. Moore. Africa, K. M. Smith (1933) suggested that this disease might be due to the same virus as yellow spot of pine apple in Hawaii and spotted wilt of tomato.

THRIPSAPHIS BALLI

1933. Yellow dwarf of onion. Onion to onion. Drake, Tate \& Harris. Iowa.

Tipula paludosa (larval form)

1927. Potato virus disease. Elze. Holland.

TOROPTERA GRAMINUM

1936. Mosaic. Sugar eane to sugar cane. Ingram \& Summers. Louisiana. Two ease only. 
TRIALENOIDES VAPORARIORUM

1930. Cucumber mosaic. Cucumber to cucumber. Bewley \& Corbett. England. One case.

TyPholoryba ULMI

1923. Leafroll. Potato to potato. Murphy. Ireland.

Zosmenus QUADRATUS

Mosaic. Beet to beet. Germany.

\section{ERRATA}

To the Index of the Vectors of Virus Diseases of Plants

Journal of the University of Puerto Rico. Vol. XIX, No. 3, pp. 407-420, 1935.

Page 413, line 6-should read Cicadulina.

Page 418, line 11-M. A. Watson writes to the compiler as follaws: "Dr. K. M. Smith's remarks applied only to Hy. II and Hy. IV, which he regards as strains of Potato mosaic. Hy. III is an entirely different virus and does not go into potato at all. $\mathrm{Hy}$. IV may be the same as Potato virus $\mathrm{X}$ but neither of these viruses is transmitted by $M$. persicae." 